\title{
Salvation in The Magic Barrel
}

\author{
Jian Xiong \\ Hohai University, Nanjing, China \\ Email: xiongjianjane@163.com
}

How to cite this paper: Xiong, J. (2018) Salvation in The Magic Barrel. Open Access Library Journal, 5: e4888.

https://doi.org/10.4236/oalib.1104888

Received: September 6, 2018

Accepted: September 26, 2018

Published: September 29, 2018

Copyright $\odot 2018$ by author and Open Access Library Inc.

This work is licensed under the Creative Commons Attribution International License (CC BY 4.0).

http://creativecommons.org/licenses/by/4.0/

\begin{abstract}
Salvation and rebirth are classical themes in Jewish fictions. The Magic Barrel depicts the life of different characters, showing their transformation from suffering to salvation. Researching the salvation can help readers to understand this novel better. So through analyzing three characters' transformations, this article researches the salvation in The Magic Barrel, and reveals that kindness and love are the origins of salvation.
\end{abstract}

\section{Subject Areas}

Literature

\section{Keywords}

Bernard Malamud, The Magic Barrel, Salvation, Rebirth

\section{Introduction}

Bernard Malamud is a Jewish writer who is adept at depicting the suffering life of Jewish [1]. The Magic Barrel is one of his most prominent short fictions which won the National Book Award for fiction. The Magic Barrel is about a young student who experienced a series of the cross of twists and turns and finally gained the salvation. The novel shows us that the suffering is not terrible, it's something that everyone should experience. Only when we use the kindness and love to deal with it, can we get the salvation and rebirth.

\section{Salvation of Leo Finkle}

Leo Finkle is the protagonist of this novel. He is a rabbinical student in the Yeshivah University and he is a knowledgeable person with a kind and lovely heart. It can show in others' comments and his ordinary behavior. He is a smart person who read many books. The matchmaker Salzman "gazed around at shelves upon shelves of books and let out a soft, contented sigh." [2]. And when he first feel 
sad about these things, he could get peace from the books. So he could tell himself "he drew the consolation that he was a Jew and that a Jew suffered" [2] and wasn't defeated by the suffering.

$\mathrm{He}$ is kindness and polite. When Salzman asked for a tea, even he is not so happy for Salzman's appearance, he "rose and brewed the tea. He served it with a chunk of lemon and two cubes of lump sugar, delighting Salzman." [2]. He is polite and he had self control which "had kept him this long in her presence." [2]. Even in the worst of his life, he could "waylaid her on the stairs and apologized abjectly" [2] for his impolite. He is honest to himself and others. He refused Salzman to call him "rabbi" [2] and tell Lily he is not "a talented religious person" [2]. He could see his shortage and face it correctly.

But he is also a normal person who lost in the big city which causes his suffering and helps him to achieve the salvation. When he first met the matchmaker, he "pretended not to see and gazed steadfastly out the window" [2]. The window is an image in the novel which represents isolation to the world and confusion to him. The view out of the windows is "signs of which he had for the first time in years begun to notice." [2]. He is like the people out of the window, having a hasty life without knowing what he wants.

The conversation is the beginning of his suffering, because he found that he didn't love people expect for his family, so he didn't have the ability to love the god [3]. This is a ruin to his world view. The novel describes it as "It seemed to Leo that his whole life stood starkly revealed and he saw himself for the first time as he truly was-unloved and loveless." [2].

The meeting to Stella is a salvation for him from the marriage dilemma and autognosis, but her identity is another suffering to Leo Finkle. He experienced a progress that "Although he soon fell asleep he could not sleep her out of his mind. He woke, beating his breast." [2].

The kindness and love helped him to solve the problems and get the salvation. He found he could marry the girl, gave her a salvation from the darkness and "convert her to goodness, himself to God" [2]. When he decided to help the girl, he got the salvation indeed.

\section{Salvation of Stella}

Stella is a character who only appeared in the ending of the novel. But according to the plot before, we can know her experience. She had a tough experience. So her father said her "Like an animal. Like a dog. For her to be poor was a sin. This is why to me she is dead now." [2]. But from the sentence we can find that her experience stems from poor. Her suffering is not because of her mistakes. She was just a female who need to get the salvation and hope to be reborn. And the author also describes her character in the feeling Leo to her. "He saw that her eyes-clearly her father's-were filled with desperate innocence." [2].

From the Judaism, Stella suffered because she had the original sin, but the suffering can help her to salvation and rebirth. Even she experienced something 
terrible, she had the innocence heart and that is why she attracted Leo. This can be seen in her dress when she waited for Leo. "She wore white with red shoes, which fitted his expectations." [2]. The white dress represented her innocence. But to the protagonist, he thought "although in a troubled moment he had imagined the dress red, and only the shoes white." [2]. He thought she needed to get the salvation because she was suffering but kept innocence. And the innocence and good virtues are the reason of salvation that she married Leo in the novel.

\section{Salvation of Salzman}

Comparing with other people, Salzman had a more complicated personality. On the one hand, he is like the fish he ate which is slippery and crafty. He was good at conjecturing the thought of people, and seizing the moment. He can choose the best time to Leo's home and avoid the period that Leo is annoyed to him. And when he first came to Leo's home, he can know Leo from the circumstance he lived. He is very calculating. When Leo met the girl, he felt that "score another for Salzman, whom he uneasily sensed to be somewhere around, hiding perhaps high in a tree along the street, flashing the lady signals with a pocket mirror; or perhaps a cloven-hoofed Pan, piping nuptial ditties as he danced his invisible way before them, strewing wild buds on the walk and purple grapes in their path, symbolizing fruit of a union, though there was of course still none." [2]. And when Leo found that the girl he loved was the daughter of Salzman, he "afflicted by a tormenting suspicion that Salzman had planned it all to happen this way." [2]. This is cunning of a Jew. It seems like a trap that all steps including the introduction and the photo left in the package.

But on another hand, he is compellent. When Leo first saw him, Leo thought "although he was missing a few teeth, his presence was not displeasing, because of an amiable manner curiously contrasted with mournful eyes" [2]. And he was responsible for her daughter, though he rumored his daughter when Leo wanted to know who she is, but it is a blame that a father had. He loved his daughter so he was toilsome. In this angle, his cunning is not wrong, and he is also suffering from the experience his daughter had.

This complicated character makes him controversial. But when we saw what the author describes him and his daughter, we can learn, that he was a person that is kindness. And in some researchers' studying, he is the guider of the protagonist.

In the end of the novel, he also got the salvation. "Around the corner, Salzman, leaning against a wall, chanted prayers for the dead." [2]. The dead is not only the former Leo and Stella, but also containing himself. It is a goodbye to the former life and the suffering they experienced.

\section{Conclusions}

Although the three characters have achieved self-redemption, their ways of redemption are different. The suffering that Leo Finkle experienced was gradually 
developed by him as he began to know himself. His character, while causing his suffering, also helped him achieve self-salvation. The suffering that Stella experienced was due to the original sin. Her character kept her innocent in her suffering and made her unable to escape this dilemma. She is a character of powerless waiting for others to redeem. Salzman's redemption method is the most complicated. He plays the character of a wise man in the novel [4]. His insight is acute and he is aware of Leo Finkle's mind, and Leo Finkle's self-awakening is largely attributed to him. By understanding Leo Finkle's emotional transformation in exploring the self, he introduced Stella to Leo Finkle at the right time, which led to the salvation of Leo Finkle and Stella. From another perspective, his own living condition in the novel is not good, and he is also experiencing the suffering of the Jews. By helping men and women to achieve salvation, he can solve his daughter's difficulties, get rewards, and realize his spiritual and practical salvation.

The novel tells us that the protagonist realized the salvation of lots of people because of his kindness and honest. He is brave to face the situation and finds the best way to save himself and others. Salvation and rebirth are the ever-lasting themes in Jewish novels [5]. And author expresses it by the little story. Suffering is normal, and it is a growth progress. What you need to do is to face the suffering and treat it as an original way and keep the kindness and love, and the salvation will come to you and people around you.

\section{Conflicts of Interest}

The authors declare no conflicts of interest regarding the publication of this paper.

\section{References}

[1] Sun, X.X. (2013) A Study on the Jewish Complex of Malamud in the Short Story "Magic Bucket". Liaoning University, Liaoning.

[2] Malamud, B. (2014) The Magic Barrel. Random House, New York.

[3] Ma, R. (2014) Interpretation of Redemption and Renaissance in The Magic Bucket. Anhui Literature (The Second Half of the Month), 5, 43.

[4] Zhao, N. (2009) The Conflict between "Prototype" and "Finalization"-Analysis of the Nature of Salzman in the Novel "Magic Bucket". Academic Exchange, 3, 186-188.

[5] Chen, H. (2010) The Performance and Transcendence of the Magic Bucket on the Jewish Theme. Journal of Hunan Medical University (Social Science Edition), 2, 161-163. 